\title{
Contribution of Xylem Anatomy to Tree-Ring Width of Two Larch Species in Permafrost and Non-Permafrost Zones of Siberia
}

\author{
Margarita I. Popkova ${ }^{1, *}$, Vladimir V. Shishov ${ }^{1,2,3}{ }^{\circledR}$, Eugene A. Vaganov ${ }^{4,5}$, Marina V. Fonti ${ }^{6,7}(\mathbb{0}$, \\ Alexander V. Kirdyanov 1,5, Elena A. Babushkina ${ }^{8}$, Jian-Guo Huang ${ }^{2,9}$ and Sergio Rossi ${ }^{9,10}$ \\ 1 Laboratory of Complex Research of Forest Dynamics in Eurasia, Siberian Federal University, \\ 660041 Krasnoyarsk, Russia; vlad.shishov@gmail.com (V.V.S.); kirdyanov@ksc.krasn.ru (A.V.K.) \\ 2 Environmental and Research Center, South China Botanical Garden, Chinese Academy of Sciences, \\ Guangzhou 510650, China; huangjg@scbg.ac.cn \\ 3 Scientific Laboratory of Forest Health, Reshetnev Siberian State University of Science and Technology, \\ 660041 Krasnoyarsk, Russia \\ 4 Rectorate, Siberian Federal University, 660041 Krasnoyarsk, Russia; research@sfu-kras.ru \\ 5 V.N. Sukachev Institute of Forest SB RAS, Federal Research Centre, 660036 Krasnoyarsk, Russia \\ 6 Laboratory of Ecosystems Biogeochemistry, Institute of Ecology and Geography, Siberian Federal University, \\ 660041 Krasnoyarsk, Russia; mbryukhanova@sfu-kras.ru \\ 7 Landscape Dynamics, Swiss Federal Research Institute WSL, CH-8903 Birmensdorf, Switzerland \\ 8 Khakass Technical Institute, Siberian Federal University, 655017 Abakan, Russia; khti@khakassia.ru \\ 9 Key Laboratory of Vegetation Restoration and Management of Degraded Ecosystems, \\ South China Botanical Garden, Chinese Academy of Sciences, Guangzhou 510650, China; \\ Sergio_Rossi@uqac.ca \\ 10 Département des Sciences Fondamentales, Université du Québec à Chicoutimi, \\ Chicoutimi, QC G7H 2B1, Canada \\ * Correspondence: mpopkova@sfu-kras.ru or popkova.marg@gmail.com
}

Received: 12 November 2020; Accepted: 15 December 2020; Published: 17 December 2020

\begin{abstract}
Plants exhibit morphological and anatomical adaptations to cope the environmental constraints of their habitat. How can mechanisms for adapting to contrasting environmental conditions change the patterns of tree rings formation? In this study, we explored differences in climatic conditions of permafrost and non-permafrost zones and assessed their influence on radial growth and wood traits of Larix gmelinii Rupr (Rupr) and Larix sibirica L., respectively. We quantified the contribution of xylem cell anatomy to the tree-ring width variability. Comparison of the anatomical tree-ring parameters over the period 1963-2011 was tested based on non-parametric Mann-Whitney $\mathrm{U}$ test. The generalized linear modeling shows the common dependence between TRW and the cell structure characteristics in contrasting environments, which can be defined as non-specific to external conditions. Thus, the relationship between the tree-ring width and the cell production in earlyand latewood are assessed as linear, whereas the dependence between the radial cell size in earlyand latewood and the tree-ring width becomes significantly non-linear for both habitats. Moreover, contribution of earlywood (EW) and latewood (LW) cells to the variation of TRW (in average 56.8\% and $24.4 \%$ respectively) was significantly higher than the effect of cell diameters (3.3\% (EW) and $17.4 \%(\mathrm{LW}))$ for the environments. The results show that different larch species from sites with diverging climatic conditions converge towards similar xylem cell structures and relationships between xylem production and cell traits. The work makes a link between climate and tree-ring structure, and promotes a better understanding the anatomical adaptation of larch species to local environment conditions.
\end{abstract}


Keywords: tree-ring structure; latewood; earlywood; number of cells; cell diameter; cell-wall thickness; climate factors; cryolithozone; forest steppe

\section{Introduction}

Tree growth depends on a number of internal and external factors and their effect on tree radial growth are reflected in the structure of the xylem [1-4]. For different forest ecosystems, climate can explain up to $40 \%-60 \%$ of the variance in the seasonal variability in tree-ring anatomy $[2,5,6]$. Due to a wide plasticity, coniferous trees are able to adapt an anatomical structure under the influence of external factors, and Larix spp. being the main tree species in the Siberian permafrost is well adapted to extreme climatic and soil conditions [7-9]. The variability of tree-ring width and its anatomical characteristics, e.g., number of cells, radial lumen size and cell-walls thickness, are closely related to the dynamics of tree-ring formation, especially to the kinetics of cell production [2,10]. Previous studies reveal an impact of the processes of cell differentiation on anatomical structure of tree rings [2,11-14]. Therefore, the endogenous factors of cell growth and maturation, combined with external conditions result in the final tree-ring structure of conifers [2,15-17].

A variety of aspects of tree-ring formation at different locations with different climate conditions show, that at high latitudes temperature is the main factor determining radial growth irrespective of the species [12,18-21]. Quantitative wood anatomy intensively developing in last decades [22-24] can be used to address research questions related to how climate affects the ring's cell structure, and how xylem anatomical parameters could be used in eco-physiological modelling [25,26].

It is still an open question how the contrasting external conditions influence the rate of tree radial growth (tree-ring width) and tree-ring structure of conifers $[2,25,27,28]$. In this study, the impact of climatic conditions on radial growth was compared between larch species growing in permafrost and non-permafrost zones in Central Siberia. The continuous permafrost zone is dominated by Gmelin larch (Larix gmelinii Rupr (Rupr). The forest-steppe zone is dominated by Siberian larch (Larix sibirica L.), a species growing on non-permafrost soils (Figure 1). Because of the contrasting growth conditions, the two environments host different species, which prevents to disentangle the species from its environment. The positive temperature trends observed at high latitudes and the existing global warming scenarios (IPCC, 2008; 2014) are stimulating potential changes in the distribution of species, namely Siberian Larch could replace Gmelin larch due to the predicted shift in permafrost further north.

We hypothesized that larch species have similar contributions of earlywood and latewood cell production and cell sizes to tree-ring width variability, but the absolute values of cell parameters (tracheid diameter and cell-wall thickness) are different due to xylem adjustment to local climate. 


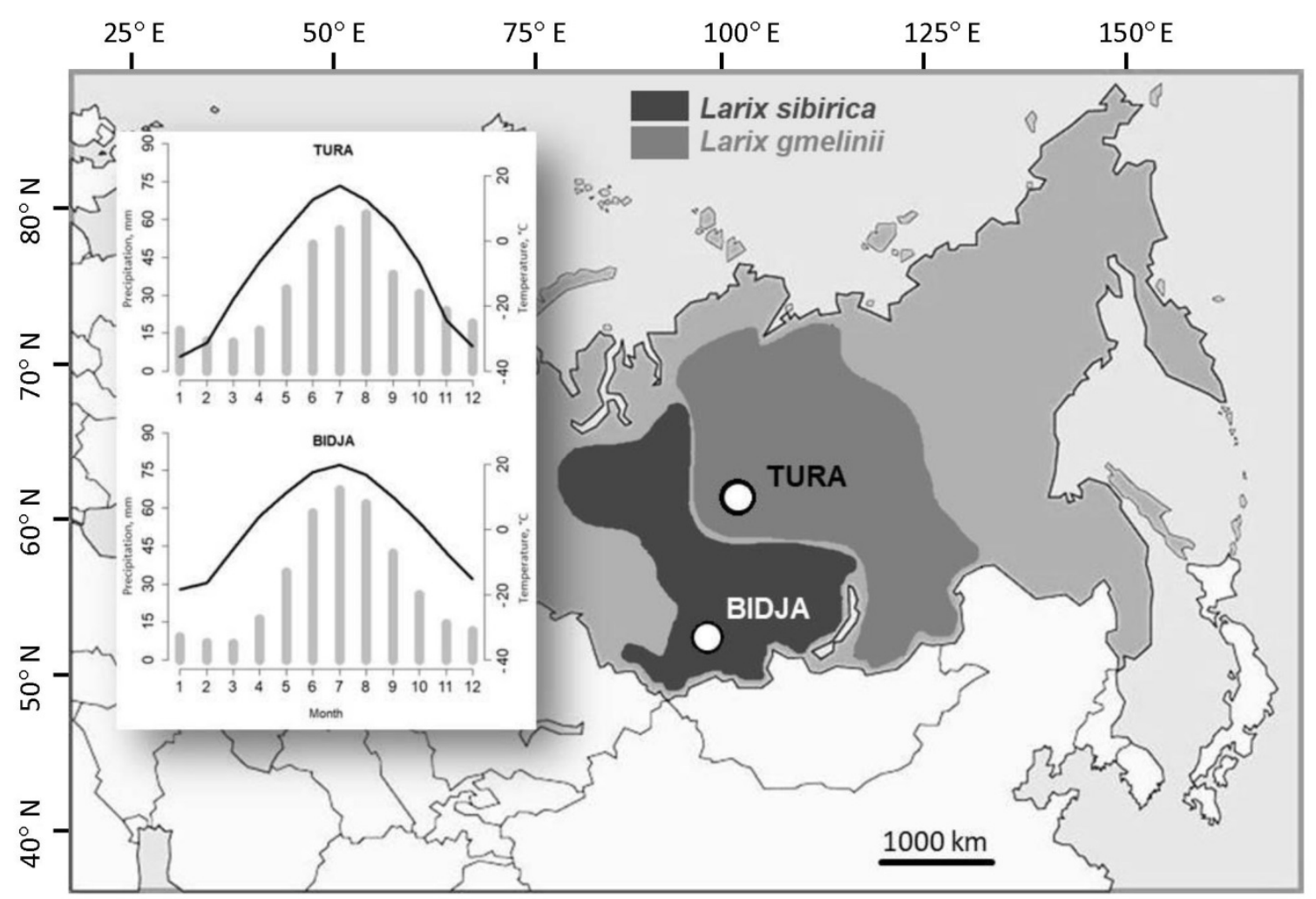

Figure 1. Map of the study area. Left panels show the climatic diagrams of the study sites with mean monthly temperature (black lines) and monthly sum of precipitation (grey bars). The meteorological data covers the common period 1963-2011. Colored zones on the map indicate areas where studied larch species (Larix sibirica L.-dark grey area; Larix gmelinii Rupr (Rupr)—light gray area) are distributed. The studied sites with tree-ring width and anatomical parameters are marked with circles.

\section{Materials and Methods}

\subsection{Study Areas and Tree Selection}

The study took place in two sites in Siberia, Russia (Figure 1). The first one (TURA; $64^{\circ} 18^{\prime} \mathrm{N}$, $100^{\circ} 11^{\prime} \mathrm{E}, 150 \mathrm{~m}$ a.s.l.) is located in continuous the permafrost zone in the northern taiga with stands mainly dominated by Gmelin larch. The climate is continental, the annual air temperature is $-9{ }^{\circ} \mathrm{C}$ and the annual precipitation is $370 \mathrm{~mm}$ according to data from the meteorological station located in the region (TURA, $64^{\circ} 16^{\prime} \mathrm{N}, 100^{\circ} 13^{\prime} \mathrm{E}, 205 \mathrm{~m}$ a.s.l.). The growing season usually starts at the end of May and ends in late August $[9,29]$. The southern site (BIDJA, $54^{\circ} 00^{\prime} \mathrm{N}, 91^{\circ} 01^{\prime} \mathrm{E}, 660 \mathrm{~m}$ a.s.l.) is located close to the Sayan-Altai Mountains and the Batenevsky Range in the forest-steppe zone. The meteorological station in Minusinsk ( $53^{\circ} 41^{\prime} \mathrm{N}, 91^{\circ} 40^{\prime} \mathrm{E}, 254 \mathrm{~m}$ a.s.l.) is located $60 \mathrm{~km}$ from the study site, with mean annual temperature of $1.0^{\circ} \mathrm{C}$ and annual precipitation of $330 \mathrm{~mm}$. BIDJA experiences a longer growing season compared to TURA, ranging between late April and early October [30]. The trees were sampled in the pine-larch open canopy forest on grey forest soils. The site is represented by Siberian larch forest mostly with 110-year old trees.

\subsection{Wood Sampling and Preparation}

Wood cores from Larix sibirica L. and Larix gmelinii Rupr (Rupr) were collected in 2012 from 16 and 18 trees in BIDJA and TURA, respectively. Annual tree-ring width (TRW) was measured with $0.01 \mathrm{~mm}$ precision using a LINTAB measuring system and program TSAP (Rinntech, Heidelberg, Germany). To control a quality of cross-dating, we used the COFECHA program [31]. TRW chronologies were detrended with negative exponential curves. An auto-regressive modeling was applied to remove 
the auto-correlations from the detrended time-series, which were averaged using a biweight robust estimate of the mean [32]. Five 100-year old trees per site characterized by the highest correlation coefficients with the site chronology (0.6-0.8) were selected for anatomical measurements. Wood cores were taken at $1.3 \mathrm{~m}$ stem height with the $5 \mathrm{~mm}$ increment borer (Haglof, Sweden) perpendicular to slope direction to avoid reaction wood.

Each core was softened by boiling in water, and thin cross sections $(20 \mu \mathrm{m})$ were cut by using a sledge microtome (Reichert, Germany) and stained with a water solution of safranin (1\%). All anatomical characteristics were measured at magnification of $400 \times$ under a microscope equipped by a digital camera (AXIOCam MRc5, Axio Imager D1; Carl Zeiss, Germany,). Five cell rows were selected in each ring to measure the number of cells (N), cell diameter (D), cell-wall thickness (CWT). Measurements were obtained with Lineyka software [33]. According to the Mork index [34], the ratio of double cell-wall thickness (2CWT) to radial size of the lumen (D) in each the ring was used to provide the sizes of zones of earlywood (EW, 2CWT < LD) and latewood (LW, 2CWT $\geq$ LD), for each of which the average values of linear and area tracheid parameters were calculated. Measurements covered the time window 1963-2011 for TURA and for one tree in BIDJA trees. The other trees in BIDJA were measured from 1976. The measurements were performed for trees $>100$ years old, when the age/tree geometry effect on tree-ring width and structure at both sites as well as the impact of post-wildfire active layer thickness changes on tree growth rate at TURA $[35,36]$ could be considered marginal.

\subsection{Dendroclimatic and Statistical Analyses}

The stability of climate-growth relations was analyzed by using a bootstrapped response function analysis [37]. The climatic signal was estimated by the Pearson correlation $(r)$ between the tree-ring indexes and monthly values of mean temperature and precipitation (from previous June to current September) from the nearest climate station by the "treeclim" package in R [38], which applies a bootstrap procedure to estimate the error using random data sets. It uses 1000 bootstrapped samples to compute response and correlation coefficients, and to test their significance at 0.05 .

Using the Mann-Whitney-Wilcoxon U Test [39], we considered whether there is a difference for two independent groups of tree-ring anatomical characteristics without assuming them to follow the normal distribution.

The effect of anatomical characteristics (number of cells and cell diameter) and site on tree ring width (TRW) was evaluated using generalized linear models (GLMs) [40]. The cell diameter, number of cells and the indicator of site were included as independent variables to quantify their effect on tree ring width. The distributions of raw data and residuals were estimated, and the relationships between cell size and TRW were linearized for the analyzed impacts. Multiple regressions were performed to assess the effects of the independent variables on TRW. The $r$-squared (coefficient of determination) interpreted as a statistical measure of how well the regression predictions approximate the real data points assume that the coefficient should be at least $50 \%$. Results with determinacy coefficient higher than $80 \%$ can be considered good enough. A sensitivity analysis was used to determine the specific contribution of each independent variable [41]. Bootstrapped t-tests were applied to evaluate the impact of the relative variations on the results of the model. T-statistics were repetitively calculated by randomly resampling the original data set and estimating the $95 \%$ confidence intervals of the distribution [42]. Bootstrapping was performed 10,000 times to improve the robustness of results [12]. Differences were considered significant when both confidence intervals were either higher or lower than zero. All transformations were performed taking into account the assumption of normality. The normality of distributions was checked based on Shapiro-Wilk's tests. All statistical analyses were performed using $R$ [43]. 


\section{Results}

\subsection{Climate Sensitivity of TRW}

Bootstrapped response function analysis was performed relating tree-ring growth to monthly mean temperature and seasonal sums of precipitation from June of the previous year to September of current year for the period 1963-2011 (Figure 2).

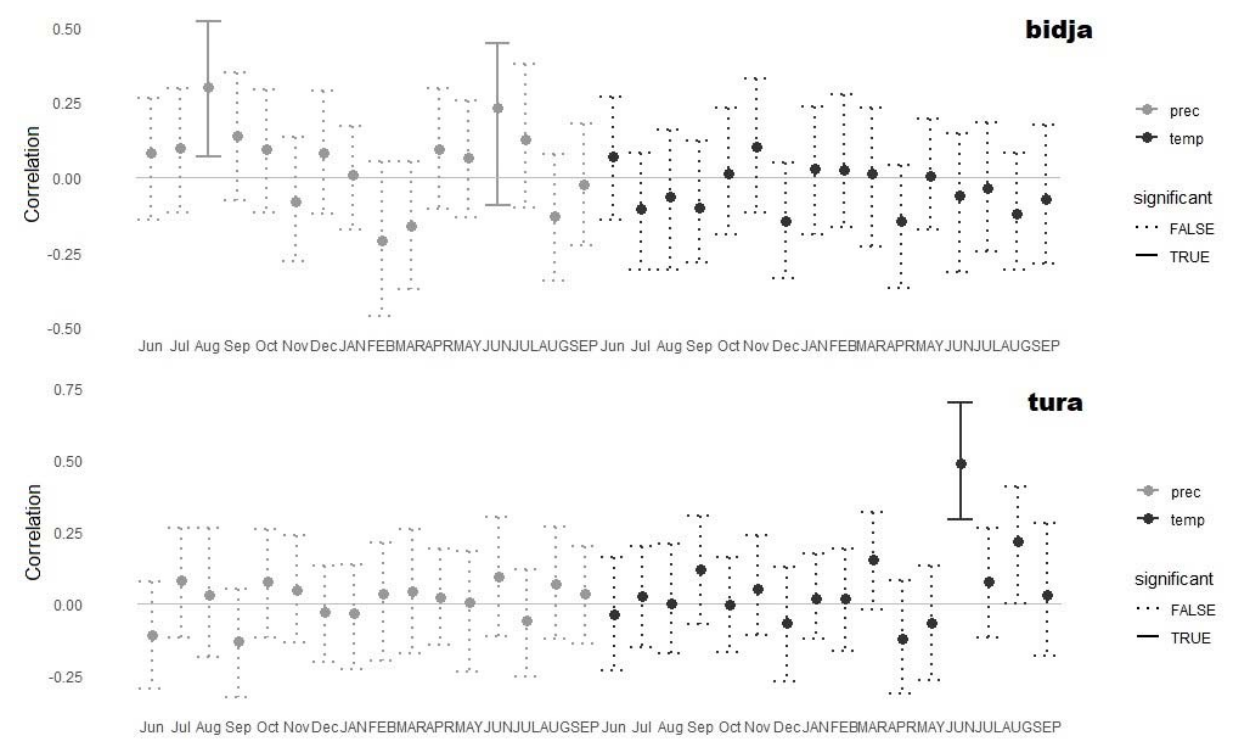

Figure 2. Bootstrapped Pearson correlations between tree-ring indices and monthly climate variables (mean temperature and precipitation) for the period 1963-2011. Monthly correlation coefficients were calculated for previous to (abbreviated by lower-case letters) and the current year of tree-ring formation (abbreviated by upper-case letters). Bold bars show significant correlations at $p<0.05$.

Results of dendroclimatic analysis of BIDJA indicate that summer precipitation in previous year August and in current year June influenced positively and significantly TRW $(r=0.31$ and $0.25, p<0.05$, respectively). At TURA, current year June temperature positively influences tree-ring growth $(r=0.57$, $p<0.05)$.

\subsection{Xylem Cell Features}

An analysis of the radial increment variability for the studied period showed different year-to-year dynamics (Figure 3). Annual rings in the southern site BIDJA were wider on 51\% than in the northern site TURA. In terms of number of cells, the annual increment for TURA trees varied from a minimum of 3 to a maximum of 37 with the average of 12 tracheids ( \pm 2.04 SD) per ring. In BIDJA the number of cells ranges from six to 73 , on average of 18 tracheids $( \pm 6.68 \mathrm{SD})$ per ring. Therefore an average cell production is a 33\% lower in TURA (Figure 3). The average cell-lumen diameters were $33.7 \mu \mathrm{m}$ and $30.1 \mu \mathrm{m}$, for BIDJA and TURA, respectively, which means a 10\% difference between the sites. Cell-wall thickness in EW was 50\% thinner in BIDJA compared with TURA (Figure 3).

A difference between the two chronologies of tree-ring anatomical characteristics estimated by Mann-Whitney U test detected the significant differences between the two sites in all lines except the cell-wall thickness in latewood (Table 1). 
EW
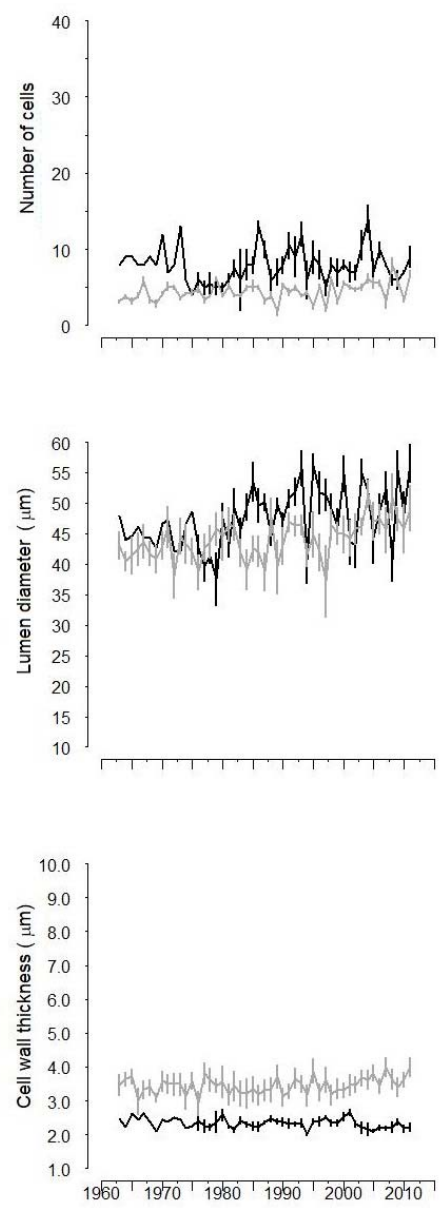

LW
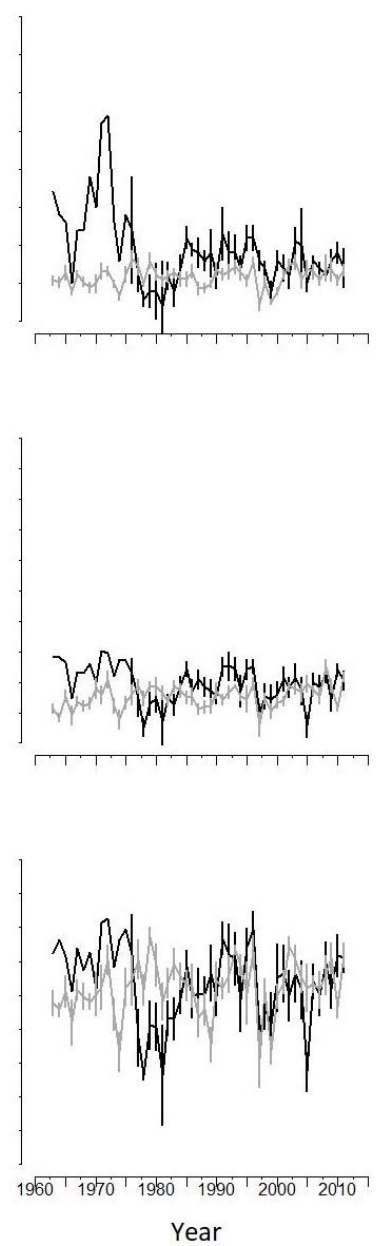

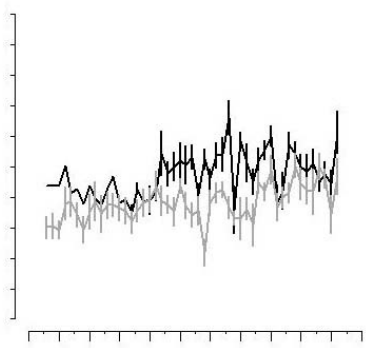

Tree-Ring
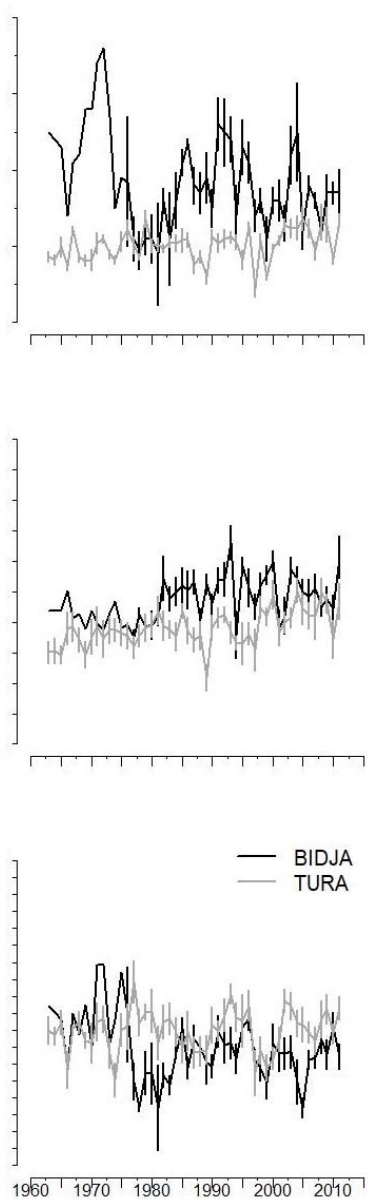

Figure 3. Mean anatomical characteristics (mean \pm standard deviation (vertical bars)) obtained for the five monitored trees from the two studied sites illustrated by number of cells, lumen diameter, cell-wall thickness in earlywood (EW) (left panel), in latewood (LW) central panel), and in total ring (Tree-Ring) (right panel).

Table 1. Estimated parameters of the Mann-Whitney U-test for anatomical characteristics of the study sites.

\begin{tabular}{cccc}
\hline & & U-Value & $p$-Value \\
\hline \multirow{3}{*}{ Number of cells } & EW & 2230 & $2.28 \times 10^{-13 *}$ \\
& LW & 1866 & $2.53 \times 10^{-6 *}$ \\
& Ring & 2236 & $2.25 \times 10^{-13 *}$ \\
\hline \multirow{3}{*}{ Lumen diameter } & EW & 1716 & $1.90 \times 10^{-4 *}$ \\
& LW & 1761 & $4.79 \times 10^{-5} *$ \\
& Ring & 2025 & $5.21 \times 10^{-10 *}$ \\
\hline \multirow{3}{*}{ Cell-wall thickness } & EW & 0 & $2.20 \times 10^{-16 *}$ \\
& LW & 1353 & $2.82 \times 10^{-1}$ \\
& Ring & 749 & $1.18 \times 10^{-3} *$ \\
\hline \multirow{2}{*}{ The sign indicates the significance; EW—earlywood; LW—latewood; Ring-total ring. }
\end{tabular}




\subsection{Relations between Main Anatomical Characteristics of Tree Rings}

The relationship between tree-ring width (TRW) and the number of cells (N) for both sites and types of wood (earlywood and latewood, EW and LW) can be considered as linear (Figure 4a,b). Pearson correlation between TRW and N in EW was 0.89 and $0.88(p<0.001)$ for TURA and BIDJA, respectively, well matching with the similar linear relationships between TRW and LW (0.91 and 0.92 ( $p<0.001)$ for TURA and BIDJA, respectively). Non-linear relationship between tree-ring width (TRW) and cell diameter (D) was observed for earlywood and latewood cells at TURA and BIDJA sites (Figure $4 c, d$ ).
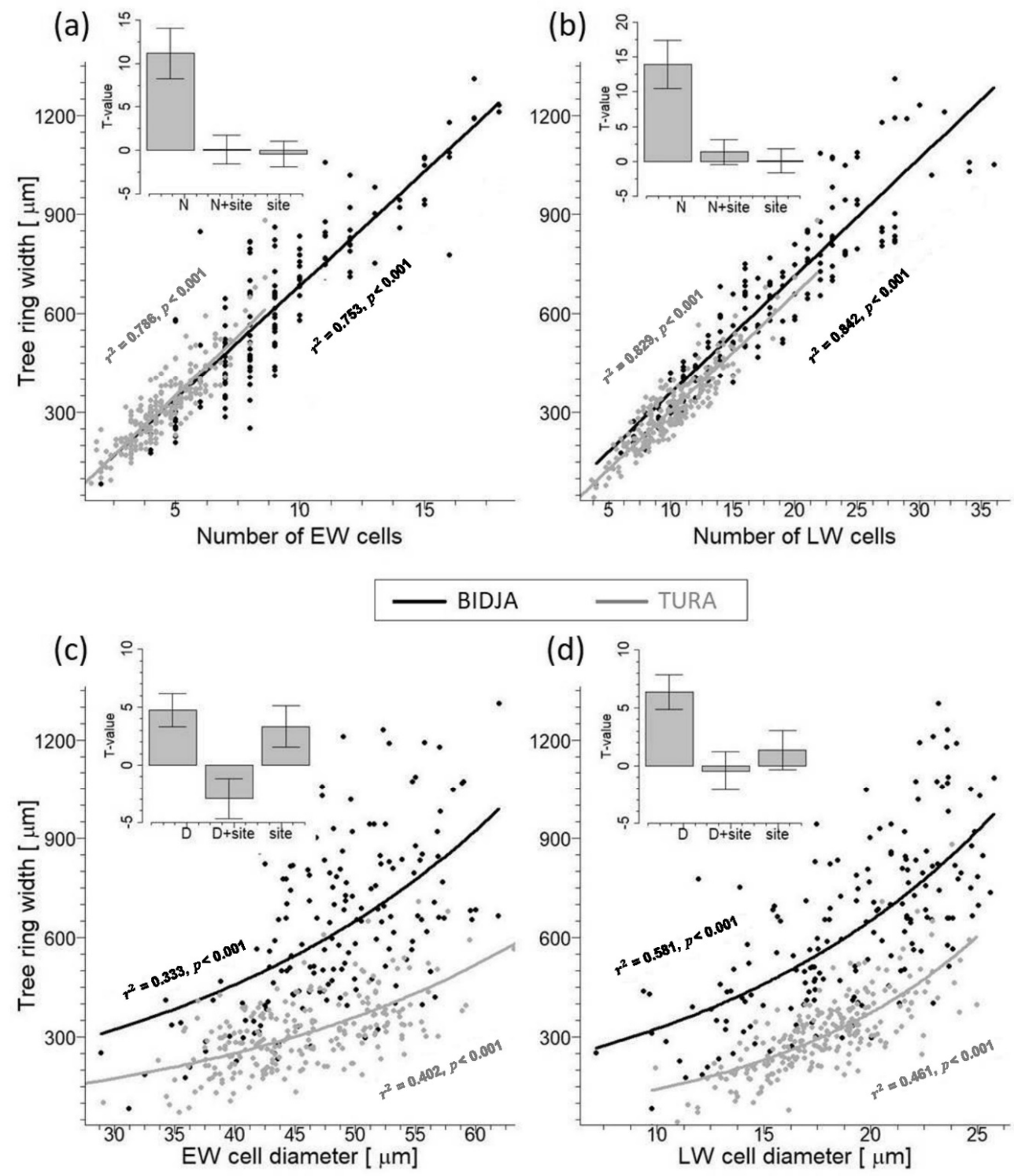

Figure 4. Linear relationships between tree-ring width (TRW) and number of cells in earlywood (EW) (a) and latewood (LW) (b). Nonlinear relationships between TRW and cell diameter in earlywood (EW) (c) and latewood (LW) (d) smoothed by an exponential function. The results are in black for TURA studied site and in grey for BIDJA studied site with corresponding $r^{2}$ and levels of significance. The enclosed vertical bars represent mean and 5\% and 95\% confidence intervals of the bootstrapped T-statistic based on 10,000 replications. A T-test is considered significant when both confidence intervals are either higher or lower than zero. 
The $r^{2}$ between TRW and D for TURA was weaker in EW $(0.33, p<0.001)$ in comparison with LW $(0.58, p<0.001)$ (Figure $4 c, d)$. For BIDJA the $r^{2}$ in EW and LW was nearly equal $(0.41$ vs. $0.46, p<0.001)$. The resulting boxplots in Figure $4 \mathrm{a}-\mathrm{d}$ show the distribution of all variables $(\mathrm{N}$, cell diameter in $\mathrm{EW}$ (LW) and site locations) that measure their significance in TRW formation. In most cases, the indicators of site were insignificant except boxplot in Figure 4c, where both confidence intervals are visibly lower than zero. If the limits at boxplots in Figure 4 were equal to zero or extremely narrow and close to zero, it was determined as statistically non-significant results.

Contribution of each anatomical parameter to the TRW variability was showed in Figure 5 resulting from the analyses performed on the two studied sites. By the results of sensitivity analysis, the effect of number of EW and LW cells on the variation of TRW was on average $56.8 \%$ and $24.4 \%$ respectively (Figure 5). Cell diameter effect was expectedly weaker representing on average, 3.3\% (EW) and 17.4\% (LW). Should also be noted the intensified influence of LW cell diameter in BIDJA, which was about a quarter $(23 \%)$ of the total variance in TRW (Figure 5).

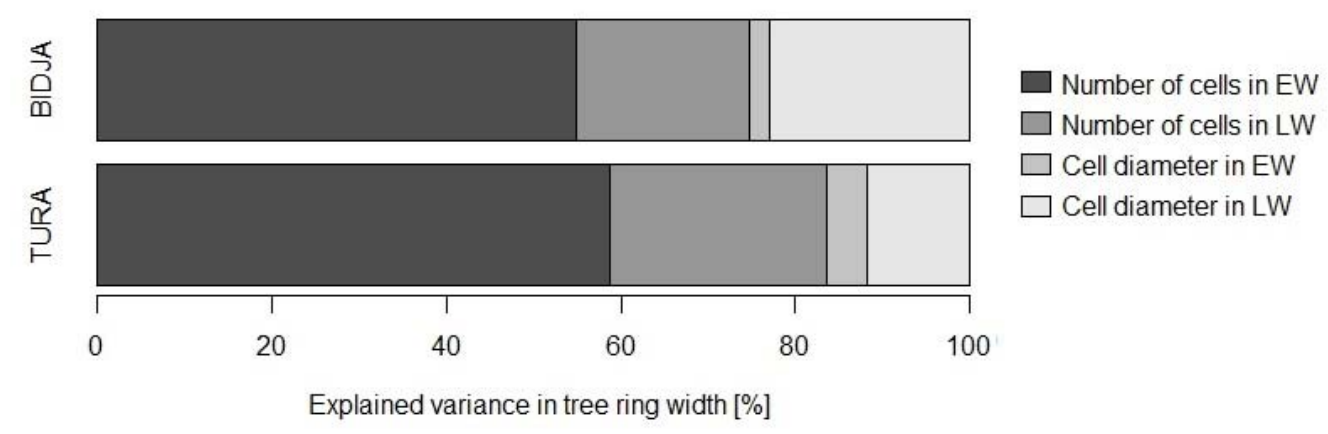

Figure 5. Contribution of number of cells and radial cell diameter in EW and LW to the total variability of tree ring width for both sites.

\section{Discussion}

This study investigated the differences in tree-ring climatic response and anatomical characteristics of xylem between two larch species growing in permafrost and non-permafrost sites. The results have showed how external factors change the tree-ring cell structure and affect the radial growth in Siberia. The monitoring involved two species because Gmelin and Siberian larch grow under different conditions and have non-overlapping distributions. Investigations of intra- and interspecific differentiation demonstrated a low genetic diversity within the larch genus, and in particular between the two study species $[8,44-46]$. This low genetic difference also results in similar wood anatomical traits. Particularly, it was shown that interpopulation genetic variability is significantly higher $(85 \%)$ within one species than interspecies differences between Larix gmelinii and Larix sibirica (15\%) [46].

The traditional dendroclimatology approach was applied to estimate the impact of climate variables on the tree-ring growth of Siberian larch and Gmelin larch. It is worth noting that significant influence of different climate factors (June temperature in permafrost site and June precipitation in southern non-permafrost site) on TRW was found. Climate-growth analysis for TURA had showed that the June temperatures had the most significant positive effect on the tree growth which confirmed by the previous results obtained for permafrost-growth larch $[47,48]$. The results obtained for BIDJA indicated the significantly positive influence of summer precipitation on tree growth. As it was noted earlier, high precipitation in late June and late July increased tree ring width of conifers in Southern Siberia $[49,50]$.

A comparison of tree-ring anatomical parameters over the period 1963-2011 showed differences of tree rings formed under contrasting (permafrost-non-permafrost) conditions (Figure 3). Due to high correlation between tree-ring width and number of cells, wider rings of larch in BIDJA have more cells in comparison with narrower rings with less cells in TURA. Further, parameters of earlywood and latewood were analyzed separately due to their adaptive response to environmental changes 
to achieve an optimal balance between competing needs for transport and mechanical functions. For studied boreal ecotones, as well as for the areas where seasonality is well pronounced, cells with large lumen and thin cell wall are considered as earlywood, while latewood cells are characterized by small lumen and wider cell wall [51,52]. One should note here that this tree-ring formation mechanism in extratropical conditions is described by some process-based models [14]. In our study it was shown that cell production of earlywood was lower under permafrost conditions in comparison to non-permafrost. The same pattern was observed for the lumen diameter of earlywood cells, namely, the EW lumens in the northern site were significantly smaller than the lumens in the southern site. It can be considered as an adjustment of the transport system to the dry conditions of Southern Siberia, as was mentioned earlier for pine at the same environment [53]. This might be also confirmed by studies that hydraulic conductivity of conifers is maximized by increasing tracheid diameters in locations where freezing is rare $[54,55]$. The narrow tracheid diameters protect against freezing-induced embolism in cold climates [56].

An opposite pattern was observed in the cell-wall thickness variability of the earlywood tracheids: The cell wall in the north (TURA) was thicker than in the south (BIDJA). However, no differences of CWT was found for latewood zone or whole ring between the sites. The thicker cell walls in latewood of trees from permafrost might be explained by the need to achieve a high mechanical strength against of harsh environmental conditions, which correspond well with other studies at North [18]. The optimization of the xylem structure to required mechanical support occurs by increasing the cell-wall area and the changing ratio of early- to latewood. A possible explanation for the phenomenon of thinner call-wall of tracheids in the southern site is relatively drier conditions, when trees faced the insufficient amount of available soil moisture due to high air temperatures and increased transpiration under limited amount of precipitation, while for trees growing in the cryolithozone it is possible to use additional sources of water from the seasonal soil thawing. In the studied conditions of Southern Siberia an increase of summer temperature with the minimum amount of precipitation or even their absence in the middle of the growing season causes a water deficit and might suppresses the processes of photosynthesis and the assimilates formation [57], which can subsequently be used to build tracheid cell walls. In this regard, the amount of precipitation in the second half of summer allows continued tree growth [58] and increases the area of the cell wall in latewood.

Obtained results confirmed our hypothesis, that absolute values of cell parameters (tracheid diameter and cell-wall thickness) are different due to xylem adjustment to local climate at permafrost and non-permafrost environment. Despite the obvious differences in the growing conditions and related tree-ring formation, relationships between TRW and the number of cells and cell diameter in EW and LW have been proven as non-specific to environmental conditions. It was shown how number of cells, cell diameter and climate specifics affect tree-ring formation in contrasting environments. Our second hypothesis that the earlywood and latewood cell production and cell sizes have a similar contribution to tree-ring width was accepted. Cell production in early- and latewood explain 56.8\% and $24.4 \%$, respectively, of the tree-ring width variability, which is fully consistent with the hypothesis of a linear relationship between total cell production, rate of cell production, and tree-ring width [2]. This relationship between TRW and the number of cells is typical to conifers from various ecological conditions. The dependence between the radial cell size in early- and latewood and the tree-ring width becomes exponential for both northern and southern sites. Only in case of dependence between the EW cell size and the tree-ring width was the site effect was significant, which requires additional analysis.

\section{Conclusions}

Climatic conditions and anatomical characteristics of L. sibirica and L. gmelinii were compared in contrasting conditions to assess their impact on radial growth. Results of bootstrapped response function analysis for southern site BIDJA indicated that summer precipitation in August of the previous year and in June of current year influenced positively tree radial growth. The same analysis for TURA revealed a significant positive correlation with the temperature of June of the current year. Tracheids 
with smaller lumen and wider cell wall were observed under permafrost conditions. The relationship between the tree-ring width and the cell production in early- and latewood are assessed as linear, whereas the dependence between the radial cell size in early- and latewood and the tree-ring width becomes significantly non-linear for TURA and BIDJA. The results show that different larch species from sites with diverging climatic conditions converge towards similar xylem cell structures and relationships between xylem production and cell traits. The relations obtained for tree-ring anatomical features of larch species in different climatic zones answer to the question on the consequences of the current warming and the associated changes in the hydrothermal regime of soils on wood growth and xylem anatomy. Our results help to clarify the link between climate and xylem functioning, and can be a tool to improve the developing models of tree growth [58,59]. This approach promotes a better understanding the anatomical adaptation of larch species to local environment conditions.

Author Contributions: M.I.P., V.V.S. and S.R. conceived and designed the study; M.V.F. and E.A.V. provided the anatomical data; A.V.K., E.A.V. and J.-G.H. provided the valuable discussion and ideas; M.I.P., V.V.S., E.A.V., M.V.F., A.V.K., E.A.B., J.-G.H. and S.R. wrote the paper. All authors have read and agreed to the published version of the manuscript.

Funding: This work was supported by the Russian Ministry of Science and Higher Education (projects \#FSRZ-2020-0010 and \#FSRZ-2020-0014) and the Russian Science Foundation [Grant 18-14-00072]. M. Popkova received a Merit scholarship for foreign students from Fonds de Recherche du Québec-Nature et Technologie (FRQNT) for completing this work. MVF was supported by RFBR and Krasnoyarsk Region (project number 18-45-240001 r_a). V.V.S. appreciates the support of the project \# FEFE-2020-0014 (Russian Ministry of Science and Higher Education).

Conflicts of Interest: The authors declare no conflict of interest.

\section{References}

1. Antonova, G.F.; Stasova, V.V. Effects of environmental factors on wood formation in Scots pine stems. Trees 1993, 7, 214-219. [CrossRef]

2. Vaganov, E.A.; Hughes, M.K.; Shashkin, A.V. Growth Dynamics of Conifer Tree Rings: Images of Past and Future Environments; Springer: Berlin/Heidelberg, Germany, 2006.

3. Babushkina, E.A.; Belokopytova, L.V.; Kostyakova, T.V.; Kokova, V.I. Earlywood and Latewood Features of Pinus sylvestris in Semiarid Natural Zones of South Siberia. Russ. J. Ecol. 2018, 49, 209-217. [CrossRef]

4. Puchi, P.F.; Castagneri, D.; Rossi, S.; Carrer, M. Wood anatomical traits in black spruce reveal latent water constraints on the boreal forest. Glob. Chang. Biol. 2019, 26, 1767-1777. [CrossRef]

5. Touchan, R.; Shishov, V.V.; Meko, D.M.; Nouiri, I.; Grachev, A. Process based model sheds light on climate sensitivity of Mediterranean tree-ring width. Biogeosciences 2012, 9, 965-972. [CrossRef]

6. Tychkov, I.I.; Sviderskaya, I.V.; Babushkina, E.A.; Popkova, M.I.; Vaganov, E.A.; Shishov, V.V. How can the parameterization of a process-based model help us understand real tree-ring growth? Trees Struct. Funct. 2019, 33, 345-357. [CrossRef]

7. Nikolaev, A.N.; Fedorov, P.P.; Desyatkin, A.R. Influence of climate and soil hydrothermal regime on radial growth of Larix cajanderi and Pinus sylvestris in central Yakutia, Russia. Scand. J. For. Res. 2009, 24, 217-226. [CrossRef]

8. Abaimov, A.P. Geographical Distribution and Genetics of Siberian Larch Species. In Permafrost Ecosystems: Siberian Larch Forests; Springer: Dordrecht, The Netherlands, 2010; pp. 41-58.

9. Bryukhanova, M.V.; Kirdyanov, A.V.; Prokushkin, A.S.; Silkin, P.P. Specific features of xylogenesis in Dahurian larch, Larix gmelinii (Rupr.) Rupr., growing on permafrost soils in Middle Siberia. Russ. J. Ecol. 2013, 44, 361-366. [CrossRef]

10. Cuny, H.E.; Rathgeber, C.B.K.; Frank, D.; Fonti, P.; Fournier, M. Kinetics of tracheid development explain conifer tree-ring structure. New Phytol. 2014, 203, 1231-1241. [CrossRef] [PubMed]

11. Vaganov, E.A.; Shashkin, A.V.; Sviderskaya, I.V.; Vysotskaya, L. Histometric Analysis of Woody Plant Growth; NAUKA Publishing House: Novosibirsk, Russia, 1985.

12. Rossi, S.; Anfodillo, T.; Cufar, K.; Cuny, H.E.; Deslauriers, A.; Fonti, P.; Frank, D.; Gricar, J.; Gruber, A.; King, G.M.; et al. Ameta-analysis of cambiumphenology and growth: Linear and non-linear patterns in conifers of the northern hemisphere. Ann. Bot. 2013, 112, 1911-1920. [CrossRef] 
13. Cuny, H.E.; Rathgeber, C.B.K. Xylogenesis: Coniferous trees of temperate forests are listening to the climate tale during the growing season but only remember the last words! Plant Physiol. 2016, 171, $306-317$. [CrossRef]

14. Cartenì, F.; Deslauriers, A.; Rossi, S.; Morin, H.; De Micco, V.; Mazzoleni, S.; Giannino, F. The physiological mechanisms behind the earlywood-to-latewood transition: A process-based modeling approach. Front. Plant Sci. 2018, 9, 1-12. [CrossRef] [PubMed]

15. Fritts, H.C.; Vaganov, E.A.; Sviderskaya, I.V.; Shashkin, A.V. Climatic variation and tree-ring structure in conifers: Empirical and mechanistic models of tree-ring width, number of cells, cell size, cell-wall thickness and wood density. Clim. Res. 1991, 1, 97-116. [CrossRef]

16. Fonti, P.; Von Arx, G.; García-González, I.; Eilmann, B.; Sass-Klaassen, U.; Gärtner, H.; Eckstein, D. Studying global change through investigation of the plastic responses of xylem anatomy in tree rings. New Phytol. 2010, 185, 42-53. [CrossRef] [PubMed]

17. Körner, C. Paradigm shift in plant growth control. Curr. Opin. Plant Biol. 2015, 25, 107-114. [CrossRef]

18. Ben'kova, V.E.; Ben'kova, A.V. Specific Features of Wood Structure in Siberian Larch Species. Lesovedenie 2006, 4, 28-36.

19. Briffa, K.R.; Shishov, V.V.; Melvin, T.M.; Vaganov, E.A.; Grudd, H.; Hantemirov, R.M.; Eronen, M.; Naurzbaev, M.M. Trends in recent temperature and radial tree growth spanning 2000 years across northwest Eurasia. Philos. Trans. R. Soc. B Biol. Sci. 2008, 363, 2269-2282. [CrossRef]

20. Hellmann, L.; Agafonov, L.; Ljungqvist, F.C.; Sidorova, O.C.; Düthorn, E.; Esper, J.; Hülsmann, L.; Kirdyanov, A.V.; Moiseev, P.; Myglan, V.S.; et al. Diverse growth trends and climate responses across Eurasia's boreal forest. Environ. Res. Lett. 2016, 11, 074021. [CrossRef]

21. He, M.; Yang, B.; Bräuning, A.; Rossi, S.; Ljungqvist, F.C.; Shishov, V.; Grießinger, J.; Wang, J.; Liu, J.; Qin, C. Recent advances in dendroclimatology in China. Earth Sci. Rev. 2019, 194, 521-535. [CrossRef]

22. Klisz, M. WinCELL-An image analysis tool for wood cell measurements. For. Res. Pap. 2009, 70, $303-306$. [CrossRef]

23. von Arx, G.; Carrer, M. Roxas-A new tool to build centuries-long tracheid-lumen chronologies in conifers. Dendrochronologia 2014, 32, 290-293. [CrossRef]

24. Dyachuk, P.; Arzac, A.; Peresunko, P.; Videnin, S.; Ilyin, V.; Assaulianov, R.; Babushkina, E.A.; Zhirnova, D.; Belokopytova, L.; Vaganov, E.A.; et al. AutoCellRow (ACR)—A new tool for the automatic quantification of cell radial files in conifer images. Dendrochronologia 2020, 60, 125687. [CrossRef]

25. Rathgeber, C.B.K.; Fonti, P.; Shishov, V.V.; Rozenberg, P. Wood formation and tree adaptation to climate. Ann. For. Sci. 2019, 76, 17-20. [CrossRef]

26. Buttò, V.; Shishov, V.; Tychkov, I.; Popkova, M.; He, M.; Rossi, S.; Deslauriers, A.; Morin, H. Comparing the Cell Dynamics of Tree-Ring Formation Observed in Microcores and as Predicted by the Vaganov-Shashkin Model. Front. Plant Sci. 2020, 11, 1-16. [CrossRef] [PubMed]

27. Arzac, A.; Popkova, M.; Anarbekova, A.; Olano, J.M.; Gutiérrez, E.; Nikolaev, A.; Shishov, V. Increasing radial and latewood growth rates of Larix cajanderi Mayr. and Pinus sylvestris L. in the continuous permafrost zone in Central Yakutia (Russia). Ann. For. Sci. 2019, 76, 96. [CrossRef]

28. Balducci, L.; Deslauriers, A.; Rossi, S.; Giovannelli, A. Stem cycle analyses help decipher the nonlinear response of trees to concurrent warming and drought. Ann. For. Sci. 2019, 76, 88. [CrossRef]

29. Ben'kova, V.E.; Schweingruber, F.H. Anatomy of Russian Woods. An Atlas for the Identification of Trees, Shrubs, Dwarf Shrubs and Woody Lianas from Russia; Haupt: Bern, Switzerland, 2004.

30. Rinne, K.T.; Saurer, M.; Kirdyanov, A.V.; Loader, N.J.; Bryukhanova, M.V.; Werner, R.A.; Siegwolf, R.T.W. The relationship between needle sugar carbon isotope ratios and tree rings of larch in Siberia. Tree Physiol. 2015, 35, 1192-1205. [CrossRef]

31. Zhirnova, D.F.; Babushkina, E.A.; Belokopytova, L.V.; Vaganov, E.A. To which side are the scales swinging? Growth stability of Siberian larch under permanent moisture deficit with periodic droughts. For. Ecol. Manag. 2020, 459, 117841. [CrossRef]

32. Holmes, R.L. Dendrochronology Program Library. 2001. Available online: https://www.ltrr.arizona.edu/pub/ dpl-mac/68k/dpl.txt (accessed on 12 November 2020).

33. Cook, E.R.; Kairiukstis, L.A. Methods of dendrochronology: Applications in the environmental sciences. Methods Dendrochronology Appl. Environ. Sci. 1990, 23, 120. 
34. Silkin, P. Methods of Multiparameter Analysis of Conifers Tree-Rings Structure; Siberian Federal University: Krasnoyarsk, Russia, 2010.

35. Denne, M.P. Definition of latewood according to mork (1928). IAWA J. 1989, 10, 59-62. [CrossRef]

36. Knorre, A.A.; Kirdyanov, A.V.; Prokushkin, A.S.; Krusic, P.J.; Büntgen, U. Tree ring-based reconstruction of the long-term influence of wildfires on permafrost active layer dynamics in Central Siberia. Sci. Total Environ. 2019, 652, 314-319. [CrossRef]

37. Kirdyanov, A.V.; Saurer, M.; Siegwolf, R.; Knorre, A.A.; Prokushkin, A.S.; Churakova, O.V.; Fonti, M.V.; Büntgen, U. Long-term ecological consequences of forest fires in the continuous permafrost zone of Siberia. Environ. Res. Lett. 2020, 15, 034061. [CrossRef]

38. Guiot, J. The bootstrapped response function. Tree Ring Bull. 1991, 51, 39-41.

39. Zang, C.; Biondi, F. treeclim: An R package for the numerical calibration of proxy-climate relationships. Ecography 2015, 38, 431-436. [CrossRef]

40. Mann, H.B.; Whitney, D.R. On a Test of Whether one of Two Random Variables is Stochastically Larger than the Other. Ann. Math. Stat. 1947, 18, 50-60. [CrossRef]

41. Bolker, B.M.; Brooks, M.E.; Clark, C.J.; Geange, S.W.; Poulsen, J.R.; Stevens, M.H.H.; White, J.S.S. Generalized linear mixed models: A practical guide for ecology and evolution. Trends Ecol. Evol. 2009, 24, 127-135. [CrossRef]

42. Cariboni, J.; Gatelli, D.; Liska, R.; Saltelli, A. The role of sensitivity analysis in ecological modelling. Ecol. Modell. 2007, 203, 167-182. [CrossRef]

43. Efron, B. Bootstrap Methods: Another Look at the Jackknife. Ann. Stat. 1979, 7, 1-26. [CrossRef]

44. R Core Team. R Development Core Team. R A Lang. Environ. Stat. Comput. 2016. Available online: http://www.R-project.org (accessed on 12 November 2020).

45. Rinne, K.T.; Saurer, M.; Kirdyanov, A.V.; Bryukhanova, M.V.; Prokushkin, A.S.; Sidorova, O.V.C.; Siegwolf, R.T.W. Examining the response of needle carbohydrates from Siberian larch trees to climate using compound-specific $813 \mathrm{C}$ and concentration analyses. Plant Cell Environ. 2015, 38, 2340-2352. [CrossRef]

46. Oreshkova, N.V.; Belokon, M.M.; Jamiyansuren, S. Genetic diversity, population structure, and differentiation of Siberian larch, Gmelin larch, and Cajander larch on SSR-marker data. Russ. J. Genet. 2013, 49, 178-186. [CrossRef]

47. Kirdyanov, A.V.; Prokushkin, A.S.; Tabakova, M.A. Tree-ring growth of Gmelin larch under contrasting local conditions in the north of Central Siberia. Dendrochronologia 2013, 31, 114-119. [CrossRef]

48. Fonti, M.V.; Fakhrutdinova, V.V.; Kalinina, E.V.; Tychkov, I.I.; Popkova, M.I.; Shishov, V.V.; Nikolaev, A.N. Long-Term Variability of Anatomic Features of Annual Tree Rings of Larch, Pine and Spruce in the Permafrost Zone in Central Siberia. Contemp. Probl. Ecol. 2019, 12, 692-702. [CrossRef]

49. Babushkina, E.A.; Vaganov, E.A.; Belokopytova, L.V.; Shishov, V.V.; Grachev, A.M. Competitive Strength Effect In the Climate Response of Scots Pine Radial Growth In South-Central Siberia Forest-Steppe. Tree Ring Res. 2015, 71, 106-117. [CrossRef]

50. Belokopytova, L.V.; Babushkina, E.A.; Zhirnova, D.F.; Panyushkina, I.P.; Vaganov, E.A. Pine and larch tracheids capture seasonal variations of climatic signal at moisture-limited sites. Trees Struct. Funct. 2019, 33, 227-242. [CrossRef]

51. Wodzicki, T.J. Mechanism of xylem differentiation in Pinus silvestris L. J. Exp. Bot. 1971, 22, 670-687. [CrossRef]

52. Deslauriers, A.; Morin, H.; Begin, Y. Cellular phenology of annual ring formation of Abies balsamea in the Quebec boreal forest (Canada). Can. J. For. Res. 2003, 33, 190-200. [CrossRef]

53. Arzac, A.; Rozas, V.; Rozenberg, P.; Olano, J.M. Water availability controls Pinus pinaster xylem growth and density: A multi-proxy approach along its environmental range. Agric. For. Meteorol. 2018, 250-251, 171-180. [CrossRef]

54. Pittermann, J.; Sperry, J.S.; Hacke, U.G.; Wheeler, J.K.; Sikkema, E.H. Inter-tracheid pitting and the hydraulic efficiency of conifer wood: The role of tracheid allometry and cavitation protection. Am. J. Bot. 2006, 93, 1265-1273. [CrossRef]

55. Mayr, S.; Cochard, H.; Améglio, T.; Kikuta, S.B. Embolism formation during freezing in the wood of Picea abies. Plant Physiol. 2007, 143, 60-67. [CrossRef] 
56. Pittermann, J.; Sperry, J. Tracheid diameter is the key trait determining the extent of freezing-induced embolism in conifers. Tree Physiol. 2003, 23, 907-914. [CrossRef]

57. Bréda, N.; Huc, R.; Granier, A.; Dreyer, E. Temperate forest trees and stands under severe drought: A review of ecophysiological responses, adaptation processes and long-term consequences. Ann. For. Sci. 2006, 63, 625-644. [CrossRef]

58. Popkova, M.I.; Vaganov, E.A.; Shishov, V.V.; Babushkina, E.A.; Rossi, S.; Fonti, M.V.; Fonti, P. Modeled tracheidograms disclose drought influence on Pinus sylvestris tree-rings structure from Siberian forest-steppe. Front. Plant Sci. 2018, 9, 1-12. [CrossRef] [PubMed]

59. Shishov, V.V.; Tychkov, I.I.; Popkova, M.I.; Ilyin, V.A.; Bryukhanova, M.V.; Kirdyanov, A.V. VS-oscilloscope: A new tool to parameterize tree radial growth based on climate conditions. Dendrochronologia 2016, 39. [CrossRef]

Publisher's Note: MDPI stays neutral with regard to jurisdictional claims in published maps and institutional affiliations.

(C) 2020 by the authors. Licensee MDPI, Basel, Switzerland. This article is an open access article distributed under the terms and conditions of the Creative Commons Attribution (CC BY) license (http://creativecommons.org/licenses/by/4.0/). 